\title{
Bhallataka Rasayana: A Boon in Cancer Treatment
}

\author{
Review Article
}

\section{Vidula A Patil ${ }^{*}$, Aarti P Dubewar ${ }^{2}$, Ramesh Bhonde 3 , Cheenu Bhargava ${ }^{4}$, Pradnya Kakodkar 5}

\begin{abstract}
1. PhD Scholar in Rasashastra \& Bhaishajya Kalpna Department, Dr. D. Y. Patil Vidyapeeth (Deemed to be University), Pune \& Assistant Professor MES Ayurved Mahavidyalaya Ghanekhunt Lote, Khed, Ratnagiri. India.

2. Head \& Professor, Rasashastra \& Bhaishajya kalpna Department, 3. Director of Research Center Regenerative Medicine, 5. Former Deputy Director, Research Committee, Dr. D. Y. Patil Vidyapeeth (Deemed to be University), Pune. India.

4. Associate Professor, Department of Pharmacology, Advance Institute of Biotech and Paramedical Sciences, Kanpur. India.
\end{abstract}

\begin{abstract}
Bhallataka (Semecarpus Anacardium) is one of the Rasayana drugs mentioned in Ayurveda. Semecarpus Anacardium plant belongs to the family Anacardiaceae having allergic expressions as contact dermatitis which originates the fear about use in mind but in Ayurveda it have been used since tradition in various diseased conditions like wounds, piles, uncontrolled cell growth, abdominal lumps etc. Despite these conditions it is more likely used as Rasayana for diseased free long life. Rasayana medicines help in rejuvenating the cells and tissues with antioxidant and cyto-protective properties. In Vitro effects of Semecarpus Anacardium extracts Bhallataka has been evaluated pharmacologically on the isolated tissues and the whole animal. The therapeutic effects of the extract are due to its chemical constituents as phenols, glycosides and lipids mainly. The review supports the information on the use of Semecarpus Anacardium extracts in different cancer conditions.
\end{abstract}

Key Words: Bhallataka, Rasayana, Cancer, Dermatitis, Extract.

\section{Introduction}

India occupies a unique position among developing countries as it has a good potential in terms of diversity and heritage of medicinal plants due to its varied climatic and soil factors.(1). India is gifted with over 40,000 species of plants by nature having importance in world health. Despite the popularization of modern medicine people still believe in herbal remedies and use them to prevent and cure many health problems.(2) Bhallataka is the one popular herb used in the traditional system of medicine for its health benefits, commonly known as the marking nut. The meaning of Bhallataka is sharp like spears. The botanical name of the plant is Semecarpus Anacardium here the word Semecarpus is derived from "Simeon" having meaning as marking in Greek and the word carpus is for nuts. The nuts of Bhallataka were used for marking hence commonly known as Marking Nut. Semecarpus Anacardium Linn. (Bhallataka) is an average-sized deciduous tree originates in all over India. Semecarpus Anacardium plant belongs to the family Anacardiaceae having allergic expressions as contact dermatitis. The

\section{* Corresponding Author:}

\section{Vidula A Patil}

$\mathrm{PhD}$ Scholar in Rasashastra \& Bhaishajya kalpna

Department Dr. D. Y. Patil college of Ayurved and

Research Centre, Dr. D. Y. Patil Vidyapeeth (Deemed to be

University) \& Assistant Professor MES Ayurved

Mahavidyalaya Ghanekhunt Lote, Khed, Ratnagiri. India.

Email Id: vidulaamitpatil@gmail.com stem, sap, fruit, and seeds are used for diverse purposes such as timber, paint, waterproofing, food, and medicine.(3) The plant grows naturally in tropical and dry climates. It is a deciduous tree about $10 \mathrm{~m}$ in height. The plant is leafless between February to April, the new leaves and flowers appear in May, the flowering season is up to October, while the fruiting time is from December to March. The fruit ovoid, drupaceous nut with a fleshy pear-shaped receptacle, up to $2.5 \mathrm{~cm}$ long and $2 \mathrm{~cm}$ broad with a black or brownish-black glossy surface.(4) Internally, the nut contains a viscous oily liquid of black color. For medicinal purposes purification of Bhallataka is necessary to avoid its allergic reactions, the nuts which are smaller in size, brownish in color, and light-weighted are not suitable for medicinal purposes because during purification such nuts float on water, this suggests such fruits are devoid of crude oil extract which is the main medicinally active part of the fruit. The acceptable variety of fruit must be sinking in water.(5). In the traditional system of medicine, it is used in skin diseases, piles, uncontrolled cell growths (Vrudhi).(6) The medicinal properties are due to its chemical constituents. In Charaka Sanhita Bhallataka (Semecarpus Anacardium) is described for Rasayana i.e. rejuvenating medicine. Rasayana is one among the great disciplines of Ayurveda, which comprises a specialized use of herbs, formulations, food articles, and lifestyle alongside self-discipline with social etiquette to realize the perfect state of body and mind health and also prevent from etiological factors affecting body.(7) In literature, the use of Bhallataka is mentioned in Vrudhi. Vrudhi is the condition when 
vitiated doshas in the body accumulate in any region; the overgrowth appears in that region. This overgrowth produces different signs and symptoms in the body like inflammation without pain and slowly growing which is co-related with cancer in the present scenario as in the initial stages of all cancers overgrowth of cells occurs but didn't get noticed due to lack of symptoms.(8)

Cancer is a diseased condition involving abnormal cell growth with the potential to invade or metastasize and variation in signs and symptoms depending on the location and type of cancer. Most cancers form masses of tissues known as tumors. In bold cancers no formation of solid tumors takes place. Cancers with tumors show lumps, relative pain in the region, and abnormal bleeding. The metabolism of the cells is not normal hence related symptoms are noticed in the patients such as fever, prolonged cough, unexplained weight loss, change in bowel movements. Uncontrolled growth in cells is due to multiple factors such as genetic make-up, diet, exposure to a carcinogen, the body's immune status, and their interaction. According to the WHO International Agency for Research on Cancer, it is the second major cause of death; (9) The Cancer burden is ever-increasing, taking a toll on human life and the world economy. Most frequently occurring and leading cause of death in men is Lung cancer followed by prostate and colorectal cancer for incidence and liver and colorectal cancer for mortality. In women, breast cancer is the most commonly diagnosed cancer and the leading cause of cancer death, followed by colorectal and lung cancer for incidence, and vice versa for mortality.(10)

Currently, in the United States, the leading cause of death is cancer accounting for about $25 \%$ of all deaths due to modernization and an advancement of life impacted by Western medicine. Causative factors for cancers act by changing the genes of cells. Hence cellular responses to the particular drug have a major role in the treatment of cancer. Multidisciplinary scientific investigations are making the best efforts to combat this disease, but the sure-shot, perfect cure is still awaited.(11)

Cancers are metabolic, genetic, or infectious in origin. Ayurveda as a part of the health management system in Asian countries approaches the philosophy of prevention and preservation as the first step to the treatment. Every system of medicine emphasizes treating the disease but in Ayurveda, treating a disease is secondary. Ayurveda aims to maintain and preserving health. To achieve this goal day to day regimen is advised with seasonal changes and diet changes, along with the implication of Rasayana.(12)

Rasayana may be thanks to achieve homeostasis for retarding the method of aging and therefore the prevention of diseases. In healthy conditions, Rasayana can be understood as nutritional dynamics for rejuvenation of the body and psyche. For restoration of normal functions of the body use of Rasayana drugs is indicated in Ayurveda. Rasayana features a definite role to play within the maintenance and preservation of health, and appropriate use of Rasayana can help to bring down the prevalence of the many diseases. Rasayana therapy helps boost immunity which helps in combating infectious causes also the immune-modulatory effects of Rasayana are helpful to normalize cell metabolism in cancer. Thus Use of Rasayana in cancer therapy ultimately reduces the healthcare burden.(13)

Research is carrying on with common herbal drugs possessing great potential for a cancer cure; scientifically these formulations work on multiple biochemical pathways and influence different organ systems altogether and nourish the body as a whole by supporting the body's defense systems. Bhallataka (Semecarpus Anacardium) is one of the Rasayana drugs mentioned in Ayurveda. (14)

\section{Morphological Characteristics of Semecarpus Anacardium}

Semecarpus Anacardium (Bhallataka) is a medium sized, deciduous tree abundant everywhere the country having fleshy nuts with dark brown to black in color, $2.5-3 \mathrm{~cm}$ long, obliquely ovoid, laterally flattened, smooth, shining with a residual receptacle. Nuts contain acrid and irritant oil which is insoluble in water and soluble in alcohol, ether, chloroform.

Dark-brown powder of dried fruit shows rosette crystals of calcium oxalate and oil globules. For therapeutic purposes, the crude oil extract of Semecarpus Anacardium is used. (15)

\section{Therapeutic uses of Semecarpus Anacardium in Ayurveda}

In Ayurveda ancient literature naming Rajnighantu(16), Bhavprakash(17) and Dhanvantari Nighantu(18) about the herbal drugs mentioned the properties of Bhallataka as Madhur and Kashaya in rasa, Ushna in virya, having Madhur vipak and laghu, Snigdha, tikshna, and ushna gunas. It acts as Kaphavatashamaka (alleviates Kapha \& Vata dosha), Bhootanashana (anti-devil) Pittashay shodhak (expels out Pitta dosha), Medhya (beneficial to the brain in memory boosting), Vrishya (aphrodisiac), Bruhan (anabolic in effect), indicated for several diseases like Arsha (hemorrhoids), Udar (ascites), Grahani (inflammatory bowel diseases), Shotha (inflammation), Krumi (Helminthiasis), Kushtha (skin disorders, like psoriasis), Vran (wounds), Shwitra (vitiligo), (abdominal mass), Jwara (fever), Adhman (Flatulence) etc. $(19,20)$.

The seed oil is employed for Rasayana purposes. Seeds (1/4th-1/2 piece) are usually administered boiled in milk and therefore the milk is consumed. The amount of pieces could also be increased gradually counting on the patient's response up to three whole nuts and subsequently, it's reduced gradually within the same fashion. The tactic of gradual dose escalation and subsequently gradual decrease of dosage over weeks is named as Vardhaman prayog in Ayurveda. The seeds oil is additionally used usually mixed with food items. For the topical purpose, the oil is applied during a minimum possible quantity or mixing it with other commonly used non-toxic oils. (21) 


\section{Phytochemicals in Semecarpus Anacardium}

Rajakrishnan $\mathbf{R}$ et al have standardized the Semecarpus Anacardium with pharmacopeia protocol and identified 11 compounds within the oil. Powder microscopy, physicochemical screening, HPTLC fingerprinting, and GC-MS analysis was done showing the results about the presence of Sugars, Flavonoids, Steroids, Saponins, Quinones, and Tannins. HPTLC profiling of the ethanol extract using Toluene/ ester (8: 1) as mobile phase revealed the presence of phytochemicals with different RF values and The GCMS analysis of the ether fraction showed the presence of 11 compounds. (22)

Goudgaon $\mathbf{N} \mathbf{M}$ et al find out the most significant components of the Semecarpus Anacardium oil as phenolic compounds. Quinones are the results of oxidation of phenolic compounds on exposure to air. Two main phenolic compounds and a glycoside are Bhilavanol A (monoenepentadecyl catechol I), Bhilavanol B (dienepentadecyl catechol IÏ), and anacardoside (glucoside). Irritation to the skin is due to these phenolic compounds. Important biflavanoids like semecarpuflavanone, jeediflavanone, galluflavanone, nallaflavanone, semecarpetin and anacarduflavanone have also been isolated. Semecarpuflavanone and galluflavanone groups have potent antioxidant activity on these flavanones. (23)

Jain Paras et al conducted the study to evaluate the phytochemicals of Semecarpus Anacardium and reported the presence of alkaloids, saponins, tannins, flavonoids, steroids, glycosides. (24)

The imminent utilization of the Semecarpus Anacardium oil in several conditions is due to its chemical constituents. Researchers conclude the presence of extractable lipids from $S$. Anacardium seeds approx. 36\%, which confirms that $S$. Anacardium seeds are an upscale source of oil. The oil contains Linoleic, Palmitic, and oleic as major fatty acids along with glycolipids and phospholipids. (25)

Kumar et al isolated 3-O-methyl quercetin and kaempferol from the stem bark. (26)

$\mathbf{N}$ Bondre \& $\mathbf{N}$ Nathar conducted the IR and NMR spectroscopic analysis of petroleum extract revealed the presence of different functional groups. The results showed the presence of secondary constituents comprising of alkaloids, flavonoids, and phenols in roots, stems, and leaves respectively. The plant is a good source of minerals like Sulphur (S), Calcium (Ca), Magnesium (Mg), Phosphorus (P), and Iron $(\mathrm{Fe}) .(27)$

H R Adhami et al extracted concentrations of active compounds and determined active compounds mainly phenols as 1_, 2_-dihydroxy-3_-pentadec-8enylbenzene (A) and $1_{-}, 2_{-}$-dihydroxy-3 pentadeca-8,11-dienylbenzene (B) by HPLC analysis. (28)

\section{Medicinal Properties of S. Anacardium}

The action of the Semecarpus Anacardium as anti-inflammatory, anti-lipidemic, hypoglycemic is due to its crude oil extract which contains phytochemicals as steroids, flavones, urushiol, etc. Research is continuing for years to evaluate the various actions of the drug. Premlata et al reported anticancer activity, anti-arthritic and antioxidant activity in the experimental study due to the constituents as linoleic acid, palmitic acid, stearic acid, arachidic acid in the seed oil.(29) Few studies have been reported on hypolipidemic activity by inhibition of cholesterol absorption.(30) hypoglycemic activity by altering the glucose metabolism(31), anti-atherogenic(32), antifungal(33), antifertility(34) and neuro protective $\operatorname{activities(35).}$

\section{In Vitro effects of Semecarpus Anacardium extracts}

Bhallataka has been evaluated pharmacologically on the isolated tissues and the whole animal.

\section{Antifungal agent}

Jain Paras et al conducted the study to evaluate the antifungal activity of methanolic extract of $S$. Anacardium against four fungal strains including Fusarium oxysporum, Rhizctonia solanine, Alternaria spp., and Sclerotium rolfsiiin different concentrations, and observed inhibitory activity. Also confirmed the more effectiveness of crude extract compared to other extracts. The results of the study provide the scientific basis for the utilization of the plant extract in future development as an antifungal. (36)

\section{Anticholinergic Action}

H R Adhami et al studied the Cholinesterase inhibitory activities of dichloromethane extract of fruits of Semecarpus Anacardium by Silico docking experiments and micro plate assay. (37)

\section{Antioxidant Action}

B Premalatha et al observed the antioxidant effect of Semecarpus Anacardium nut extract to assess the anti-tumor activity. The activity is observed in liver and kidney homogenates. The harmful effects due to the running down of antioxidants are controlled by the administration of Semecarpus Anacardium nut extract which resulted marked increase in antioxidant levels and a dramatic elevation in cytochrome P450 content. (38)

\section{Anti-inflammatory}

D Singh et al evaluated a crude ethanol extract of Semecarpus Anacardium nuts for its antiinflammatory activities in vitro using peripheral blood and synovial fluid mononuclear cells of healthy individuals and rheumatoid arthritis (RA) patients and observed inhibition of spontaneous production of proinflammatory cytokines IL-1_ and IL-12p40 with no any effect on $\mathrm{TNF}_{-}$and $\overline{\mathrm{IL}}-6$ production, both at protein and mRNA level. (39)

\section{Cytoprotective Action}

Kumar et al studied the cytoprotective effect of 3-O-methyl quercetin and kaempferol extracted from stem bark against hydrogen peroxide-induced cytotoxicity in lung and liver cells. The cytoprotective 
action is due to stress reduction and increased expression of the nuclear factor erythroid 2-related factor 2 (Nrf2) which is the regulator of cellular resistance to oxidants and superoxide dismutase-2 enzyme that helps break down potentially harmful oxygen molecules in cells. The Cytoprotective action is due to flavonoids of the Semecarpus Anacardium. (40)

\section{In vivo hypo-lipidemic activity}

Dwivedi et al experimented on obesity-induced rats for anti-hypo- the lipidemic activity of Semecarpus Anacardium formulation mentioned in Charaka Sanhita as Rasayana and observed the lowering serum cholesterol on treated with the formulation Bhallataka Kshoudra Rasayana.(41) The action of cholesterollowering is due to inhibition of dietary cholesterol absorption or esterification. In this process two enzymes are involved, pancreatic cholesterol esterase and intestinal acyl Co-A-cholesterol acyl transferees enzyme (ACAT), thus it is suggested the Bhallataka kshoudra Rasayana inhibit the activity of one or both of these enzymes due to the presence of lipids in the crude oil. (42)

\section{Anticancer activity of Semecarpus Anacardium oil In leukemia}

D Sugapriya et al studied the Semecarpus Anacardium Linn. Nut milk extract (SA) for its antileukemic activity in leukemic mice and observed clearance of the leukemic cells from the bone marrow and internal organs on histopathological examination and this was confirmed by RT-PCR for the p210 mRNA. Semecarpus Anacardium extract-treated group reversed the changes in levels of the lipid peroxides, the glycolytic enzymes, the gluconeogenic enzymes, and the mitochondrial enzymes without any side effects. (43) Further research was carried to find out the mechanism of action of SA by assessing its antiproliferative and apoptotic effects in the BCReABLp 12B1 murine leukemic cell line and observed the mitochondrial apoptotic effect in myeloid leukemia cell lines which assured by observing the typical apoptotic morphological changes on propidium iodide staining and DNA ladder formation on electrophoresis. The effectiveness of Semecarpus Anacardium milk extract is by the restoration of deranged energy metabolism in leukemic cells. These effects of SA are amid down regulation of $\mathrm{Bcl}-2$, up regulation of $\mathrm{Bax}$, and activation of the caspase- 3 and caspase- 9 genes. (44)

S Chakraborty et al carried out the cellular level study of the cytotoxic activity of Semecarpus Anacardium nut oil and observed cytotoxic effect on four human tumor cell lines: acute myeloblastic leukemia (HL-60), chronic myelogenic leukemia (K-562), breast adenocarcinoma (MCF-7), and cervical epithelial carcinoma (HeLa) and no cytotoxic towards normal human lymphocytes, suggesting their action is specific for tumor cells. (45)

\section{In vivo study in Breast cancer}

K Veena et al studied the Siddha preparation Kalpamruta containing Semecarpus Anacardium Linn.
(SA), Emblica Officinalis and honey on breast cancerinduced animals to study the lipid metabolism and observed the reversal of the increased levels of total cholesterol, free cholesterol, phospholipids, triglycerides, and free fatty acids along with decreased levels of ester cholesterol in plasma, liver, and kidney found in cancer suffering animals on treatment with $K A$. (46)

P Mathivadhani et al tested Semecarpus Anacardium for its inhibitory effect on human breast cancer cells (T47D) and observed cytotoxicity by apoptotic signals in T47D cells.(50) Also demonstrates the antitumor activity of Semecarpus Anacardium extracts is due to the suppression of hypoxic and angiogenesis. (47)

\section{In breast cancer cell lines}

Banuhaseena et al evaluate the apoptotic and cyto protective effect of the drug Semecarpus Anacardium on the MCF-7 breast cancer cell line. The apoptotic effect of the drug SA on MCF-7 cells was determined by the trypan blue exclusion method and cytotoxicity was determined by lactate dehydrogenase (LDH) assay. (48)

\section{In pancreatic cell lines}

J S Falconer et al studied the ability of fatty acids of Semecarpus Anacardium to inhibit of growth of pancreatic cell lines.(49)

\section{In vivo study in Hepatocellular carcinoma}

Semecarpus Anacardium Nut milk extract administered orally at a dose of $200 \mathrm{mg} / \mathrm{kg} /$ day for 14 days exerted an in vivo stabilizing effect on lysosome membrane and glycoprotein content in rat hepatoma. Such stabilization of bio-membranes by Semecarpus Anacardium nut extract may have a beneficial effect within the treatment of hepatoma and other cancers involving abnormal fragility of lysosomes and glycoprotein content providing the extract demonstrates safety during a full toxicity study. (50)

Joseph et al determined the anti-cancerous efficacy of Semecarpus Anacardium (SA) nuts milk extract in hepatocellular carcinoma induced in animals. During the study, both liver enzymes and HCC marker were increased in hepatocellular carcinoma control along with neoplastic changes in the liver and were decreased in the Semecarpus Anacardium nut milk extract-treated group. (51)

Surya Prabhu et al studied the antioxidant activity of $S$. Anacardium leaf extract on liver cancer cell lines against the reactive oxygen species using Nitric oxide radical scavenging assay and observed inhibition percentage of $42.28 \pm 0.069$ at $5 \mu \mathrm{g} / \mathrm{ml}$ and $53.03 \pm 0.069$ at $25 \mu \mathrm{g} / \mathrm{ml}$ respectively showing a significance value. The in-vitro anticancer activity of $S$. Anacardium on normal cell lines and cancer of the liver cell lines (HepG2) showed a decline in cell viability percentage with the rise in sample concentration. (52) 


\section{In epidermoid larynx carcinoma}

Sanjay R Patel et al studied the anticancer activity of methanolic extract of Semecarpus Anacardium nut on the human epidermoid larynx carcinoma cell line (Hep 2) in 96 microplate formats and found effective inhibition of growth of cells. (53)

\section{In cervical cancer cell lines}

Mallic $M$ et al experimented on $\mathrm{HeLa}$ and $\mathrm{SiHa}$ cell lines for the determination of cytotoxicity of Semecarpus Anacardium ethanolic extract and observed cytotoxic activity in both the cell lines due to the presence of toxic flavones. (54)

\section{Summary \& Conclusion}

Bhallataka (Semecarpus Anacardium L.) is useful in various diseases in the Indian system of medicine. Preparations of the nut from Semecarpus Anacardium are being used in ancient medicine and find also effective in contemporary researches. The present review summarizes its anticancer effect. Considering the conducted researches to date it is observed that there is no single mechanism of action that supports the role of the drug in cancer. The action of Semecarpus Anacardium oil in the cancer cell lines is cytotoxic to cancer cells and cytoprotective to normal cells. The cytoprotective effect is due to the presence of flavonoids in it. The extract is with anti-oxidant properties which prevent harmful effects due to the dropping of anti-oxidant levels. Liver functions and kidney functions improve with the administration of Semecarpus Anacardium extract. Thus overall systemic functions get improved in cancer due to the synergetic actions of the extract. The phytochemical reviews support the presence of different active phyto constituents as alkaloids, lipids, phenolic compounds, tannins, glycosides, vitamins, and minerals. Current cancer therapy as radiotherapy, chemotherapy is not fully effective against cancer and comes with various unwanted effects as nausea, vomiting, weight loss, secondary infections due to low immune response. In such conditions, we need to add on the effect of holistic science like Ayurveda. The healing approach in Ayurveda is mainly maintenance of health with the restoration of normal function. Researches are conducted to study the effect of Rasayana therapy in cancer and different metabolic disorders. According to contemporary parameters, Rasayana therapy acts as antioxidant therapy. Bhallataka (Semecarpus Anacardium) is one of the important Rasayana drugs mentioned in Ayurveda. Various formulations of Bhallataka are explained in Rasayana chikista which needs pieces of evidence of action in diseases. The review supports the information on the use of Semecarpus Anacardium extracts in different cancer conditions. The data from recent studies is necessary to overcome the toxicity stigma of the drug. Thus Semecarpus Anacardium will act as a potent anticancer drug due to its cytotoxic nature to cells, antioxidant properties, and anti-inflammatory effects. The development of safe and palatable combinations with this drug is the need of time. In Ayurveda literature formulations mentioned as Rasayana are the hopes for the development of new combinations in pharmaceutical science. Thus the present article is the review of the traditional use of Semecarpus Anacardium, its phytochemicals and specific actions of phytochemicals in the treatment of cancer, and the role of Semecarpus Anacardium as rejuvenating medicine.

\section{References}

1. Jha, S. K., Jain, P., \& Sharma, H. P., Xenobiotic degradation by bacterial enzymes, Int. J. Curr. Microbiol. App. Sci, (2015), 4(6), 48-62

2. Jain, Paras, H. P. Sharma, and Suniti Chaudhary. "Ethno-Medicinal Plants used by Tribal Communities of Jharkhand for Prevention and Remedy of Cancer." International Journal of Agriculture Innovations and Research 6.2 (2017): 2319-1473.

3. Kumar, Ashwini \& Raut, Ashwinikumar \& Sawant, N \& Amonkar, Ashok \& Vaidya, Ashok, Bhallatak (Semecarpus Anacardium Linn.)-A Review, Indian journal of traditional knowledge, (2007), 6.

4. Semalty M, Semalty A, Badola A, Joshi GP, Rawat MS. , Semecarpus Anacardium Linn.: A review., Pharmacogn Rev. $2010 ; 4(7): 88-94$. doi:10.4103/0973-7847.65328

5. Sadananda Sharma, Rasa Tarangini. Hindi translation, edited by Pandit Kashinath Shastri, 11 th Edn, reprint. Varanasi: Motilal banarasidasa Publication, 2004; page no. 734.

6. Shanth Kumar Lucas D, Dravyaguna -vijnana, Vol II, Varanasi, Choukhamba Vishvabharati, Reprint 2015, ISBN978-93-81301-31-9, page no 87-92.

7. Goyal, Mandip. "Rasayana in perspective of the present scenario." Ayu 39.2 (2018): 63.

8. Kaviraj Ambikadutta Shastri, Ayurvedtatvadipika hindivyakhya, Sushrut Samhita, reprint edition, Varanasi, Choukhambha Publications, 2005, Nidan sthan $11 / 21,355$

9. Jain, Paras, H. P. Sharma, and Suniti Chaudhary. "Ethno-Medicinal Plants used by Tribal Communities of Jharkhand for Prevention and Remedy of Cancer." International Journal of Agriculture Innovations and Research 6.2 (2017): 2319-1473

10. Sung, Hyuna, et al. "Global cancer statistics 2020: GLOBOCAN estimates of incidence and mortality worldwide for 36 cancers in 185 countries." $C A$ : $a$ cancer journal for clinicians 71.3 (2021): 209-249.

11. Balachandran, Premalatha, and Rajgopal Govindarajan. "Cancer-An Ayurvedic perspective." Pharmacological research 51.1 (2005): 19-30.

12. Pandit Kashinatha Shastri, Charaka Sanhita, Part 1, Seventh Edition, Varanasi, Chaukhambha Publications, 2002, Sutrasthana Chapter 5, page no. 73-92.

13. Goyal, Mandip. "Rasayana in perspective of the present scenario." Ayu 39.2 (2018): 63. 
14. Pandit Kashinatha Shastri, Charaka Sanhita Part 2, Seventh Edition, Chaukhambha Publications, Varanasi, 2002, Chikistasthana Chapter 1-2, page no. 21-23

15. Ayurvedic Pharmacopoeia of India, Part I, volume II, Government of India, ministry of Health \& family welfare department of Indian system of Medicine \& Homeopathy, first edition, Delhi, The controller of publications civil lines, 110054, ISBN81-901151-03

16. Indradeo Tripathi, Rajnighantu of Pandit Narhari, edited with Dravyagunaprakashika Hindi commentary, second edition, Varanasi, Krishnadas Academy, 1998, page no. 352- 353

17. Krishnachandra Chunekar, Bhavprakash Nighatu edited by Late Dr. G. S. Padey, Varanasi, Choukhambha Bharati Academy, reprint year 2013, page no. 134-137

18. Guru Prasad Sharma, Aacharya Priyavat Sharma, Dhanvantari nighantu, Varanasi, Choukhamba Oriental, Reprint 2012, page no 114.

19. Sharma PV, Dravyaguna Vijnana, Vol II, Varanasi, Choukhambha Bharati Academy, Page no 166.

20. Kumar, Ashwini \& Raut, Ashwinikumar \& Sawant, N \& Amonkar, Ashok \& Vaidya, Ashok. Bhallatak (Semecarpus anacardium Linn) - A Review. Indian journal of traditional knowledge. (2007), 6 .

21. Pandit Kashinatha Shastri, Charaka Sanhita Part 2, Seventh Edition, Varanasi Chaukhambha Publications, 2002, Chikistasthana Chapter 1-2, page no. 21-23.

22. Rajakrishnan R, Samuel D, Lekshmi R. Analytical standards of fruits of Bhallthaka-Semecarpus Anacardium Linn. J Ayu Herb Med, 2016;2(1):20-25

23. Goudgaon N M, Lamture J B \& Nayak U R, Semecarpus Anacardium as an anticancer agent: Epoxy derivatives of the monoene and dienebhilawanols, Indian Drugs, 22 (11) (1984) 556.

24. Paras Jain, Soni Kumari Singh, H. P. Sharma and Fauziya Basri: Phytochemicals Screening and Antifungal Activity of Semecarpus Anacardium L. (An Anti-Cancer Plant). Int J Pharm Sci Res 2014; 5(5): 1884-91.doi: 10.13040/IJPSR.0975-8232.5 (5).1884-91

25. Ramadan, M. F., Kinni, S. G., Seshagiri, M., \& Morsel, J. T. Fat-soluble bioactives, fatty acid profile and radical scavenging activity of Semecarpus Anacardium seed oil. Journal of the American Oil Chemists' Society, (2010). 87(8), 885-894.

26. Kumar, A. N., Bevara, G. B., Kaja, L. K., Badana, A. K., \& Malla, R. R. Protective effect of 3-Omethyl quercetin and kaempferol from Semecarpus Anacardium against $\mathrm{H}_{2} \mathrm{O}_{2}$ induced cytotoxicity in lung and liver cells. BMC complementary and alternative medicine, (2016). 16(1), 1-13.

27. Bondre V N and Nathar V N, Phyto-constituents, proximate and mineral composition of Semecarpus Anacardium 1. An ethnomedicinal plant,
International Journal of Current Research, June, 2011 Vol. 3, Issue, 6, pp.423-428,

28. Adhami, H. R., Linder, T., Kaehlig, H., Schuster, D., Zehl, M., \& Krenn, L. Catechol alkenyls from Semecarpus Anacardium: acetylcholinesterase inhibition and binding mode predictions. Journal of ethnopharmacology, (2012). 139(1), 142-148.

29. Premlatha B, Semecarpus Anacardium Linn. nuts A boon in alternative medicine, Indian J Exp Biol, (2000), 38 (12) 1177.

30. Sharma A, Mathur R and Dixit V P, Hypocholesterolemic activity of nutshell extract of Semecarpus Anacardium (Bhilawa) in cholesterolfed rabbits, Indian J Exp Biol, 1995, 33, 444-8.

31. Aseervatham, Jaya, Shanthi Palanivelu, and Sachdanandam Panchanadham. "Semecarpus anacardium (Bhallataka) alters the glucose metabolism and energy production in diabetic rats." Evidence-based complementary and alternative medicine 2011 (2010).

32. Tripathi, Y. B., and R. S. Pandey. "Semecarpus Anacardium, nuts inhibit lipopolysaccharide induced NO production in rat macrophages along with its hypolipidemic property." (2004).

33. Patil Aarti \& Sadat Quazi (2019).Antifungal Activity of Semecarpus Anacardium Linn. Oil against selected phytopathogenic fungi. Pla. Sci.2019; Vol. 02 Iss. 03:42-44

34. Sushma, Y., Kulkarni, G., \& Singh, S. Antifertility Activity of Aqueous and Ethanolic Extracts of Semecarpus Anacardium Fruit in Female Albino Rats. International Journal of Pharmaceutical Sciences and Research, (2016). 7(3), 1235

35. Vijayakumar, N., \& Subramanian, P. Neuroprotective effect of Semecarpus Anacardium against hyperammonemia in rats. J Pharm Res, (2010). 3, $1564-8$.

36. Jain, P., Singh, S. K., Sharma, H. P., \& Basri, F., Phytochemical screening and antifungal activity of Semecarpus Anacardium (An anti-cancer plant). Int J Pharmaceut Sci Res, (2014), 5(5), 1884-1891

37. Adhami, H. R., Linder, T., Kaehlig, H., Schuster, D., Zehl, M., \& Krenn, L. Catechol alkenyls from Semecarpus Anacardium: acetylcholinesterase inhibition and binding mode predictions. Journal of ethnopharmacology, (2012), 139(1), 142-148

38. Premalatha, B., \& Sachdanandam, P. Semecarpus Anacardium L. nut extract administration induces the in vivo antioxidant defense system in aflatoxin B1 mediated hepatocellular carcinoma. Journal of ethnopharmacology, (1999), 66(2), 131-139

39. Singh, D., Aggarwal, A., Mathias, A., \& Naik, S. Immunomodulatory activity of Semecarpus Anacardium extract in mononuclear cells of normal individuals and rheumatoid arthritis patients. Journal of ethnopharmacology, (2006), 108(3), 398-406.

40. Kumar, A. N., Bevara, G. B., Kaja, L. K., Badana, A. K., \& Malla, R. R. Protective effect of 3-Omethyl quercetin and kaempferol from Semecarpus Anacardium against $\mathrm{H}_{2} \mathrm{O}_{2}$ induced cytotoxicity in 
lung and liver cells. BMC complementary and alternative medicine, (2016), 16(1), 1-13.

41. Nariya, M. B., Dwivedi, M. K., Galib, R., \& Prajapati, P. K., Anti-hyperlipidaemic effects of fresh and cured Bhallataka Kshaudra (Semecarpus Anacardium L.) in animals. Indian Journal of Natural Products and Resources (IJNPR), [Formerly Natural Product Radiance (NPR)], (2018), 9(2), 143-150.

42. Gallo, L. L., Clark, S. B., Myers, S., \& Vahouny, G. $\mathrm{V}$ Cholesterol absorption in rat intestine: role of cholesterol esterase and acyl coenzyme A: cholesterol acyl transferase. Journal of lipid research, (1984). 25(6), 604-612.

43. Sugapriya, D., Shanthi, P., \& Sachdanandam, P., Restoration of energy metabolism in leukemic mice treated by a siddha drug-Semecarpus Anacardium Linn. Nut milk extract. Chemico-biological interactions, (2008), 173(1), 43-58.

44. Dhanasekaran, S., Jaganathan, R., Panchanadham, S., \& Palanivelu, S. Induction of mitochondrionmediated apoptosis by Semecarpus Anacardium in the $\mathrm{BCR}-\mathrm{ABL}+12 \mathrm{~B} 1$ leukemia cell line: possible mechanism of therapeutic action in vivo. Journal of Experimental \& Clinical Medicine, (2012). 4(1), 30-38.

45. Chakraborty, S., Roy, M., Taraphdar, A. K., \& Bhattacharya, R. K. ,Cytotoxic effect of root extract of Tiliacora racemosa and oil of Semecarpus Anacardium nut in human tumour cells. Phytotherapy Research: An International Journal Devoted to Pharmacological and Toxicological Evaluation of Natural Product Derivatives, (2004). 18(8), 595-600.

46. Veena, K., Shanthi, P., \& Sachdanandam, P. The biochemical alterations following administration of Kalpaamruthaa and Semecarpus Anacardium in mammary carcinoma. Chemico-biological interactions, (2006). 161(1), 69-78.

47. Mathivadhani, P., Shanthi, P., \& Sachdanandam, P. Apoptotic effect of Semecarpus Anacardium nut extract on T47D breast cancer cell line. Cell biology international, (2007), 31(10), 1198-1206.

48. Khan, H. B. H., Panchanadham, S. T., \& Palanivelu, S., Apoptotic and cytotoxic effect of Semecarpus Anacardium Linn nut milk extract on MCF-7 breast cancer cells. Comparative Clinical Pathology, (2015), 24(6), 1439-1444.

49. Falconer, J. S., Ross, J. A., Fearon, K. C. H., Hawkins, R. A., O'riordain, M. G., \& Carter, D. C. , Effect of eicosapentaenoic acid and other fatty acids on the growth in vitro of human pancreatic cancer cell lines. British journal of cancer,) (1994, 69(5), 826-832.

50. Premalatha, B., \& Sachdanandam, P., Stabilization of lysosomal membrane and cell membrane glycoprotein profile by Semecarpus Anacardium Linn. nut milk extract in experimental hepatocellular carcinoma. Phytotherapy Research, (2000), 14(5), 352-355.

51. Joseph, J. P., Raval, S. K., Sadariya, K. A., Jhala, M., \& Kumar, P. ,Anticancerous efficacy of Ayurvedic milk extracts of Semecarpus Anacardium nuts on hepatocellular carcinoma in wistar rats. African Journal of Traditional, Complementary and Alternative Medicines, (2013), 10(5), 299-304.

52. Surya Prabha, U, Cojandaraj, L., \& Milton, M. J., Phytochemical screening, gc-ms analysis, antioxidant activity and in vitro anticancer activity of leaf extract of Semecarpus Anacardium. Linn (anacardiaceae). Journal of Advanced Scientific Research, (2020). 11(2).

53. Patel, S. R., Suthar, A. P., \& Patel, R. M, In Vitro Cytotoxicity activity of Semecarpus Anacardium extract against hep 2 cell line and vero cell line, Int J PharmTech Res, (2009), 1, 1429-33.

54. Mallick, M., Khan, W., Singh, M., Najm, M., Kashif, M., Ahmad, S., \& Husain, S. A. In vitro anticancer potential of Semecarpus Anacardium Linn. Drug Development \& Therapeutics, (2016), 7(1). 